\title{
Investigating Nigerian-European Union Relations: A Focus on the EU's Strategic Interests in Nigeria since 1999
}

\author{
Olukayode Bakare \\ Department of Politics and International Relations, School of Social Science, University of Aberdeen, Scotland, UK \\ Email: olukayodebakare@yahoo.com
}

How to cite this paper: Bakare, O. (2019) Investigating Nigerian-European Union Relations: A Focus on the EU's Strategic Interests in Nigeria since 1999. Open Journal of Social Sciences, 7, 233-242. https://doi.org/10.4236/jss.2019.76019

Received: May 15, 2019

Accepted: June 24, 2019

Published: June 27, 2019

Copyright ( 2019 by author(s) and Scientific Research Publishing Inc. This work is licensed under the Creative Commons Attribution International License (CC BY 4.0).

http://creativecommons.org/licenses/by/4.0/

\section{Open Access}

\begin{abstract}
This paper investigates the strategic and diplomatic relationships between Nigeria and EU following the return of the Nigerian state to the civilian rule in 1999. However, Nigeria's foreign relations with the EU dated to 1970s when it led a group of forty-six African, Caribbean and Pacific states (ACP) during the negotiation between the European Economic Community (EEC), which led to the formation of the Lomé Convention of 1975. Nigeria's leadership role towards the creation of the Lomé Convention of 1975 was a significant marker in its efforts to promote and advance economic ingratiation between the ACP and EEC (now the EU). Given the historical antecedents of the Nigerian-EU relations from the 1970s till the late 1990s, however, this paper argues that, following the return to democracy in 1999, new multilateral diplomacy had to be embarked upon to engage constructively with the international community in respect to challenges of peace, security, development, and democracy. To achieve these strategic objectives, Nigeria has constructively partnered with the European Union (EU) in five areas-good governance, developmental co-operation, regional security, energy, and trade. Nonetheless, Nigerian relations with EU had improved following its return to civil rule in 1999. But the relationship has always been asymmetrical and predicated on the motivation of the European Union to advance its strategic interests in Nigeria.
\end{abstract}

\section{Keywords}

Democracy, European Union, Foreign Relations, Good Governance, Gulf of Guinea, Nigerian Strategic Interests, Security

\section{Introduction}

The European Union (EU) is a supranational, intergovernmental decision-making 
institution established to foster deep economic co-operation and political integration between European countries [1]. Nigeria's relations with the EU dated to the 1970s when it led a group of forty-six African, Caribbean and Pacific states (ACP) during the negotiation between the European Economic Community (EEC) (now EU), which culminated in the formation of the ACP-EEC Lomé Convention on 28 February 1975, in Lomé, Togo [2]. The Lomé Convention of 1975 created an institutional platform of a very significant North-South solidarity and dialogue that could be explored through an effective leadership, facilitate economic cooperation and development between the EEC and the EU, though the partnership agreement was only partially completed in 2011 and remained a subject of controversy and contradiction [3]. However, the most far-reaching and recent agreement signed between the EU and Nigeria was the 2000 Cotonou Agreement. It represents the most comprehensive regional and partnership agreement between developing countries and the European Union. Since 2000, the agreement has been a policy framework for the EU's partnership with 79 countries from African, Caribbean and Pacific countries (ACP), Asia and Latin America, Mediterranean countries and the Middle East and Eastern neighboring countries [4], to facilitate socio-economic and political integrations. Although, Nigerian relations with the EU had improved following its return to civil rule in 1999, the relationship has always been asymmetrical and predicated on the motivation of the European Union to advance its strategic interests in Nigeria.

The main reason for embarking on this research is to investigate Nigerian diplomatic relations with the EU and the EU's strategic interest in Nigeria following its return to democracy in 1999. For example, Istifanus Zabadi noted that "when military rule was replaced with democratic rule in May 1999, a new multilateral diplomacy had to be embarked upon" [5]. After Nigeria's return to democracy in 1999, the international context required the country to engage constructively with the global community in respect to challenges of peace, security, development and democratization at home and across Africa [5].

However, the literature review of studies on Nigeria-EU relations after the return to democracy in 1999, rarely offers a comprehensive study on the EU's interests in Nigeria since 1999. Most of these scholarly works are of a limited, prescriptive and descriptive nature. Many are monographs, articles, and textbooks published by governmental bodies, authors and scholars. Scholars and authors tend to focus on a gamut of peripherals about the Nigerian strategic environment, relating to its foreign and security policy, corroborating and reflecting different national, theoretical and analytical perspectives, yet few of these works are analytical and theoretical: they explain little about the implications of Nigeria's strategic security and foreign policy behavior in reference to the EU's strategic interests in the country. Also, fewer consider the question of interest in this paper, namely what constitutes the character and degree of change in the practice of Nigeria's foreign policy and related security behavior with the EU since democratization (1999). This paper is, therefore, seeking to address this gap. This dichotomy (Nigeria-EU relations) is discussed below from four main pers- 
pectives-good governance, developmental co-operation, regional security, energy, and trade. The objective of this paper is to investigate the strategic relationships between Nigeria and EU since 1999.

\section{Nigeria-EU Relations: Democracy and Good Governance}

Following the return of Nigeria to civilian government in 1999, Nigeria has consistently repositioned itself in the EU to advance its national interests. For example, in 2009, the two parties signed the Nigeria-EU Joint Way Forward which highlights guidelines for developmental co-operation; focusing on certain priority areas: peace and security, good governance and human rights, trade and energy [1], although the logic of the EU partnership and interests in Nigeria since 1999 seems to be based on purely strategic objectives of the EU interests in Nigeria.

The most far reaching and recent treaty on democracy and good government was the Cotonou Agreement signed in 2000 between the EU and the ACP. Article 9(1) of the Cotonou Agreement affirms that respect for human rights, democracy and good governance are anchored on the rule of law; "transparent and accountable governance is an integral part of sustainable development" [6]. Similarly, the EU Africa Strategy 2005, which aims to provide a comprehensive integrated approach for EU-African relations, also emphasizes "good and effective governance" as a "central prerequisite for sustainable development" [7]. In contrast to this, however, previous analysis of the EU's commitment to the promotion of democracy and good governance in ACP has suggested an inconsistent engagement with this principle by the EU [8]. In fact, the EU tends to prioritize its strategic interests when democratization processes and good governance in Member States seem to clash and be asymmetrical with its own policy objectives. The EU's continued relations, at various points, with several countries in Africa, including Ethiopia, Rwanda, Nigeria, Kenya and Chad, where dubious elections have taken place, demonstrates the EU's inability, or disinterest, in upholding article 9, which specifies respect for the rule of law and good government [8]. In respect to Nigeria, Anna Khakee noted that promotion of democracy and good governance tended not to be the top priority of EU-Nigerian relations, but rather oil and trade relations [9].

Political problems including migration, Nigeria's status as a regional power, the country's weak internal political system and the EU's own economic and political interests have also compromised the EU's engagement in the promotion of Nigerian democracy. For example, the 2007 general election, which was considered by the international community as the most fraudulent election conducted in Nigeria, did not attract any suspension of aid or invocation of the Cotonou Agreement either by the European Commission, European Council or EU Member States [7]. The constitutional amendment of the third term bid of former Nigerian President Olusegun Obasanjo in 2005-2007 and the compromised position of the Independent National Electoral Commission (INEC) cast doubt 
on how the EU treats undemocratic states [9].

\section{Nigeria-EU Relations: Developmental and Economic Aid}

In the past decade, several events and actions have characterized EU-Nigerian (EU-African) relations beyond the consideration of the promotion of democracy and good governance in Nigeria. At the international level, global inequality and the need to improve basic livelihoods became the key focus of the international community, as encapsulated in the Millennium Development Goals (MDGs) and the creation of the Doha Development Agenda (DDA). In sub-Saharan Africa, the emergence of the New Partnership for Africa's Development (NEPAD), the African Union (AU) and ECOWAS created a constructive platform for international donors to render economic development aid to Africa [10]. Following the return of Nigeria to democracy in 1999, which also coincided with the creation of the economic strategies of NEPAD, championed by Thabo Mbeki, the quest for developmental economic aid from the international donors within the EU became the top priority of African leaders as an integral part of the AU's aim to reduce poverty in Africa [10]. Consequently, the first assistance package of $€ 100$ million from 1999-2000 was accompanied with the signing of the Cotonou Agreement in 2000 and EU-Nigerian strategic assistance to Nigeria worth $€ 600$ million in 2002. The EU, through the European Development Fund (EDF), granted Nigeria the sum of $€ 650$ million over the period of 2002-2007 (European Union Commission, 2010) [6]. Between 2008 and 2013, €580 million was allocated to Nigeria from the EU [7]. The EU development assistance to Nigeria is derived from its regional status as the most populous country in Africa and as an important regional actor in regional security and economic development in West African sub-region [5].

The EU and its Member States remain the largest aid donors to Africa. This policy is to aid the Millennium Development Goals (MDGs) and other development initiatives with their African partners. In 2009, the EU donated EUR 20.5 billion to the African continent [6]. Since 2000, however, development policy and programmes have undergone significant reforms, with the creation of the Europe Aid external co-operation office in 2001, targeting African, Caribbean and Pacific countries (ACP), Asia and Latin America, Mediterranean countries and the Middle East and Eastern neighboring countries continent [6]. Nigeria has the highest concentration of poverty in Africa, and ranks third in the world [11], with the majority of the population living on less than $\$ 1.90$ a day [12]. The level of poverty, hunger and underdevelopment in Nigeria thus underlined the EU's developmental interest in Nigeria. It must be stressed that this interest in Nigeria is not unconnected with Nigeria's resource-based economy. The level and pattern of the EU's actions as a strategic and regional partner in Nigeria tends to be as a "developmental strategy and development enabler", however [13]. The EU's development initiatives in Nigeria contrasts with its prominent donor role in neighboring nations, however. Nigeria represents Africa's most 
under-funded country in terms of its ODA/GNP ratio from the EU.

The European Commission and the British government stand as the only two European donors of any significant measure. In 2003, Britain allocated \$43 million compared to \$10 million donated by the commission for the period 2001-07 [14]. UK development initiatives are therefore the largest of the EU, at a projected EUR400 million for 2001-11 [7]. Corroborating such figures in perspective, however, Nigeria's annual GDP was reported to be $\$ 568.5$ billion in 2014 [12]. Member States overseas development aid to Nigeria in fact surpasses that of the Commission, with the largest percentage of the contributions coming from Britain, and a small fraction emanating from Germany, France and Denmark, among others [15]. The EU's scanty attention in Nigeria over the years has been attributed to lack of progress in combating corruption, especially in the energy sector [14]. Apart from the prevailing corruption which has impacted negatively on the EU aid to Nigeria, it must be affirmed Nigeria's aid dependency on the EU is low when compared with some African countries that also benefit from EU aid. For example, in 2007, official development assistance from the EU to Nigeria was 1.7 per cent behind other countries in Africa [7]. Consequently, donors cannot set policy priorities in Nigeria, but rather abide by and accept whatever policy actions the Nigerian government decides [7]. It must also be stressed that lack of leverage, oil wealth and corruption on the part of the $\mathrm{Ni}$ gerian government are responsible for the EU's scanty and poor developmental aid to Nigeria [7].

\section{Nigeria-EU: Military Co-Operation}

The 2016 European Union Strategy for Security and Development in the Sahel emphasized security as an essential factor to strengthen African countries economies and to reduce poverty on the continent [16]. The key nexus between development and security is also predicated on support for good democratic governance which is couched as "fundamental for poverty reduction" and whose absence is part of the "root causes of violence conflicts and development" [17]. Instability and conflicts in Africa thus pose a range of threats and security challenges for Europe. Africa's extremism, terrorism and vastly increasing migration through the Mediterranean Sea, as well as cross-border crimes, all have divergent implications for security in Europe. By demographic trends, Africa has the world's fast-growing population and lack of economic fortune in many African nations ensures that the urge to travel in search of better prospects in Europe will persist. The European Union (EU) has an inherent and considerable interest in a stable Africa [18] and especially in Nigerian stability [15].

European Union interests in the Nigerian security architecture describe Nigeria as an important regional economic partner for the European Union's economic investments in Africa. The European Union (EU) is a major importer of Nigerian oil and gas exports (around $20 \%$ of crude oil and $80 \%$ of gas) and a major current and potential investor in Nigeria [19]. The need to protect the Gulf of Guinea (the volatile oil region) and to encourage stable regional partners 
for its own wellbeing is imperative for the EU and its member states. Threats to peace and development such as extreme poverty, climate change, frequent food crises, rapid population growth, fragile governance, corruption, unresolved internal tensions, violent extremism and radicalization, illicit trafficking [20], and illegal cross-border movements originating from Nigeria are potentially destabilizing for European security [15]. The EU security interest in Nigeria further focuses on terrorist threats, including Boko Haram [15].

Given the above, two areas of co-operation have been crucial in the EU-Nigerian security relationship since 1999. The first focuses on sales of arms and the second focuses on the regional security architecture between Nigeria and the EU. Arms exports to Nigeria from the EU were improved following the end of military rule in the country in 1999. The UK became the largest arms exporter, followed by Italy and Germany. In 2004, Nigeria was licensed to import aircraft, ground vehicles, and other categories of military equipment worth $€ 82$ million [9].

On regional security co-operation, the EU seeks to work with key emerging African regional powers such as Nigeria, South Africa and Ethiopia to promote security in the Sahel [21]. For example, on 25 October 2011, the EU Foreign Affairs created a European Strategy for Security and Development in the Sahel. The European Sector Social Dialogue (ESSD) was the first regional security approach designed by the European Union Commission (EUC) in Africa. The security approach also involves developing effective security strategies with regional organisations such as ECOWAS and the AU in the fight against terrorism and trafficking [22].

Following the establishment of the ESSD, the Sixth Nigeria-EU Ministerial Dialogue was held in Brussels on 15 March 2016. The dialogue underlined the importance and key role of Nigeria in the promotion of peace and security within ECOWAS and the AU Peace and Security Council. The two parties agreed to strengthen efforts towards tackling the increasing security challenges emanating from Mali and Libya and the continuing instability posed by the Islamic State of Iraq and the Levant (ISIS). The parties expressed commitment to tackle security challenges such as terrorism, cross-border crimes, proliferation of small and light weapons, and human trafficking [16].

On the Gulf of Guinea, Nigeria and the EU noted that maritime security is crucial for the growth and development of the region. To strengthen maritime security, Nigeria expressed its commitment to the established organisational security architecture and the "operationalization of Inter-Regional Coordinating Centre (ICC) and the appointment of a single focal point to address maritime security issues" [16]. On the side of the EU, it affirmed its commitment to strengthening domestic legislations and facilitating effective synergy and dialogue between Nigeria and the EU [16].

\section{Energy and Trade}

Another key area of EU strategic relation with the Nigerian state has to do with the energy sector and trade. The European Union's energy interests in Nigeria 
rest on three fundamental objectives: sustainability, competitiveness and security [21]. Nigeria has the second largest oil reserves in Africa after Libya and is the second largest primary oil producer in Africa. The country's 37.2 billion barrels of oil reserves rank it among the top 10 countries in terms of oil reserves globally [23]. In 2011, Nigeria's oil production capacity was around 3.23 million bpd [23]. In fact, Nigeria's largest crude oil export destinations include Canada, France, China, Italy, Indonesia, India, South Africa, Spain and the United Kingdom. India remains the highest and most consistent buyer of Nigeria's crude oil with 16.2 billion barrels in January 2016 [24]. Despite weak historical links with Nigeria, France still has a strong energy interest in Nigeria. On October 20, 2015, France donated $\$ 170$ million which was aimed at improving the power supply for the Federal Capital Territory (FCT).

The French government also signed an agreement with the Federal Government of Nigeria to build a 35 million Euro ( $\$ \$ 8$ billion) 13 megawatts solar plant in Osun state, Nigeria [25]. In addition, about $12 \%$ of the UK's crude oil imports currently emanate from Nigeria, with the UK Chamber of Commerce commenting on the increasing rate of piracy and threats in the region. The UK Chamber of Commerce argues that the levels of threats in the Niger Delta region of Nigeria heavily expose the UK economy to lawlessness off the coast of Nigeria [26]. Equally, German energy interests in Nigeria have been unveiled in Liquefied Natural Gas (LNG) [26]. Nigeria's quest to expand its Liquefied Natural Gas market into Europe was underpinned by a German delegation to Nigeria [27].

Nigeria will continue to remain a global important producer of oil and natural gas for the EU. The oil rich Niger Delta region of Nigeria provides lucrative opportunities to the European Community and affects the world economic market, thus making Nigeria potentially one of the richest economies in sub-Saharan Africa, with lucrative and enticing market opportunities for the private sector in telecommunications, manufacturing, pharmaceuticals and defence [28].

\section{Conclusion}

This paper analyzed the relations between Nigeria and the European Union (EU) since the return to civilian rule in 1999. These relations cut across the three strategic levels-democracy and good governance, developmental cooperation, security relations, energy and trade. Accordingly, Nigerian-EU relations since 1999 placed more strategic emphasis on security and energy, rather than advancing democracy in the Sahel. EU foreign policy towards Nigeria also focused on developmental aid. EU developmental aid to Nigeria was based on the perception that Nigeria is the most populous country in Africa and most of the population live in abject poverty, although the EU developmental aid to Nigeria has been quite low compared to some other African countries [7]. The government of Nigeria has not helped the situation, however. For example, Andrew Youngs noted that the scant attention given to Nigeria by the EU in relation to developmental aid can be attributed to fears of corruption [14], and guided go- 
vernmental policies which are outside the control and influence of the EU [7]. Security relations between the two parties have been improved, however, especially with a view to securing and protecting the Gulf of Guinea against existential threats that may impair the EU's access to the oil in the region. The need to protect the interests of the EU in the realization of its strategic goal in Nigeria further underscored the improved security relations between the parties. Ultimately, the EU foreign policy objectives in Nigeria have been to enhance development and secure the Niger Delta, thereby guaranteeing its continuous access to the oil and gas in the region.

\section{Conflicts of Interest}

The author declares no conflicts of interest regarding the publication of this paper.

\section{References}

[1] Abidde, S.O. (2017) Nigeria’s Niger Delta: Militancy, Amnesty, and the Post-Amnesty Environment. Lexington Books, London.

[2] Adetula, V. (2008) Nigeria and the European: The Lomé Years and Beyond. In: Jones, Basil R. Ed. Europe at the Crossroads. Nova Science Publisher, Inc., New York, 133-151.

[3] Whiteman, K. (2012) Introduction. In: Adekeye, A. and Whiteman, K., Eds., The EU and Africa: From Eurafrique to Afro-Europa, C. Hurst \& Co., London, 1-22.

[4] European Union Commission (2010) Evaluation Carried out on Behalf of the European Commission. Final Report, Vol. 2.

https://ec.europa.eu/europeaid/sites/devco/files/evaluation-cooperation-ec-nigeria1276-annex-201005 en 3 0.pdf

[5] Zabadi, I.S. (2004) Nigeria's New Multilateral Diplomacy. In: Akinterinwa, B.A., Ed., Nigeria's New Foreign Policy Thrust. Essays in Honour of Ambassador Oluyemi Adeniji, CON, Vantage Publishers, Ibadan, 333-357.

[6] European Union Commission (2000) The Cotonou Agreement, Article 9. European Commission. http://www.europarl.europa.eu/intcoop/acp/03 01/pdf/mn3012634 en.pdf

[7] Khakee, A. (2010) Nigeria: Conflict, Energy, and Bad Governance. In: Youngs, R., Ed., The European Union and Democracy Promotion: A Critical Global Assessment, The Johns Hopkins University Press, Baltimore, 175-196.

[8] Biondo, D.K. (2011) EU Aid Conditionality in ACP Countries: Explaining Inconsistency in EU Delegation of European Union to Nigeria and ECOWAS. Journal of Contemporary European Research, 7, 1-16.

http://eeas.europa.eu/delegations/nigeria/eu nigeria/political_relations/index en.ht $\underline{\mathrm{m}}$

[9] Khakee, A. (2007) EU Democracy Promotion in Nigeria: Between Realpolitik and Idealism. Fride, Madrid.

[10] Carbone, M. (2013) The EU-African Relations in the Twenty-first Century: Evolutions and Expectations. In: Carbone, M., Ed., European Union in Africa: Incoherent Policies, Asymmetrical Partnership, Manchester University Press, Manchester, 3-24. 
[11] Omoh, G. (2011) Nigeria, Third on World Poverty Index-World Bank. http://www.vanguardngr.com/2014/04/440695/

[12] World Bank (2016) Poverty Headcount Ratio at \$1.90 a Day (2011 PPP) (\% of Population). https://data.world/gpsdd/f4c696b3-fad6-47a8-b0fe-f9308a0ff7b9

[13] Bello, O. (2012) Nigeria's Boko Haram Threat: How the EU Should Act. Fride, Policy Brief.

[14] Youngs, R. (2009) What Role for Sub-Saharan Africa in Europe's Energy Policies? http://www.edc2020.eu/fileadmin/Textdateien/EDC 2020 Work paper No 5.pdf

[15] Friel, E. (2014) Riding or Reaping the Whirlwind? An Account of the EU's Engagement with Insecurity in Northern Nigeria. EU Diplomacy Paper No. 9.

[16] European Union External Action Service (2016) Strategy for Security and Development in the Sahel.

http://www.eeas.europa.eu/archives/docs/africa/docs/sahel strategy en.pdf

[17] Youngs, R. (2007) Fusing Security and Development: Just Another Euro-Platitude? Centre for European Policy Studies. CEPS Working Document No. 277.

https://doi.org/10.2139/ssrn.1337977 https://papers.ssrn.com/sol3/papers.cfm?abstract id=1337977

[18] Dick, Z., Hoebeke, H., Merket, H. and Meijnders, M. (2015) The EU as a Security Actor in Africa. In-Depth Study Clingendael Monitor 2016.

https://www.clingendael.nl/sites/default/files/EU as a security actor in\%20Africa In-depth study Clingendael Monitor 2016.pdf

[19] Calleja, R.R. (2013) Nigeria: Risks and Opportunities for Spain and Europe. https://diplomacystatusquo.wordpress.com/2013/08/29/nigeria-risks-and-opportun ities-for-spain-and-europe/

[20] European Union (2016) Delegation of the European Union to Nigeria and ECOWAS. https://eeas.europa.eu/delegations/nigeria en

[21] Zeniewski, P., et al. (2013) Framing New Threats: The Internal Security of Gas and Electricity Networks in the European Union. In: Dyer, H. and Trombetta, M.J., Eds., International Handbook of Energy Security, Edward Elgar Publishing Limited, Cheltenham, 40-69.

[22] Cathelin, M. (2011) EU's Africa Foreign Policy after Lisbon Conference Report. Conference Report by Chatham House, Brussels, 1-9.

[23] Resursi, P. (2013) Oil and Gas in Africa: Africa's Reserves Potential and Prospects.

https://www.resourcedata.org/hr/document/rgi-oil-and-gas-in-africa-africa-s-reserv es-potential-and-prospects

[24] Eze-Kanu, C. (2016) US purchase of Nigeria's Crude Rises to $12.1 \mathrm{mb}$ in February. https://www.today.ng/business/127127/purchase-nigerias-crude-rises-12-1mb-febru $\underline{\operatorname{ary}}$

[25] Onwuemenyi, O. (2016) France Renews Interest in Nigeria's Power Sector with $\$ 170 \mathrm{~m}$ Grant.

http://sweetcrudereports.com/2015/10/20/\%E2\%80\%8Efrance-renews-interest-in-ni gerias-power-sector-with-170m-grant/

[26] UK Chamber of Commerce (2014) Nigerian Piracy 'a Major Threat' to Seafarers and the UK Economy, New Study Shows.

https://www.ukchamberofshipping.com/latest/nigerian-piracy-major-threat-seafare rs-and-uk-economy-new-study-shows/ 
[27] Kachikwu, I. (2016) Germany Signals Interest in Nigeria.

https://www.thenewsnigeria.com.ng/2016/02/germany-signals-interest-in-nigerias-1 ng/

[28] Goldman, A. (1999) Nigeria: Many Problems, Few Solutions. In: Haass, R.N., Ed., Trans-Atlantic Tensions. The United States, Europe, and Problem Countries, Brookings Institution Press, Washington DC, 205-226. 